\title{
Demographics and District Managers' Commitment to Inter-organisational Collaboration during Disasters'Management in Ghana
}

\author{
Dr. N. Osei OWUSU \\ Department of Management \\ School of Business \\ University of Cape Coast \\ Cape Coast, Ghana \\ E-mail: nowusu@ucc.edu.gh
}

Received: Aug. 15, 2019 Accepted: Feb. 19, 2020 Online published: Mar. 15, 2020

doi:10.5296/jpag.v10i1.16674 URL: https://doi.org/10.5296/jpag.v10i1.16674

\begin{abstract}
This paper aims at examining whether the demographic features of public managers make a difference in terms of their commitment to inter-organisational collaboration in Ghana during disasters' management. Using quantitative method, questionnaires were distributed to 195 public district managers from Ashanti region but with a return rate of 87\%, 170 managers responded to the questionnaires. The data were analyzed using SPSS software (Version, 22). In analysing the data, descriptive frequencies, analysis of variance with Independent-samples t-test and one-way ANOVA, together with the Pearson's correlation analysis were employed to present the study results. Additionally, to further understand the extent of the various demographic factors' influence on managers' commitment to inter-organisational collaboration the regression analyses were performed. From the bivariate analysis, the demographic variables used were: educational qualifications, age, gender, tenure, and marital status. The empirical results suggested that indeed inter-organisational collaboration is influenced by the demographic characteristics of district managers. In particular, the extent of inter-organizational collaboration was found to be influenced positively by gender, tenure of office, age and educational qualifications but negatively influenced by their marital status. It was therefore recommended that in order to ensure effective inter-organisational collaborative activities amongst public managers during disasters, the individual characteristics should be taken into consideration in the strategic plans of public organizations.
\end{abstract}

Keywords: disasters, Inter-organisational collaboration, commitment, district, Ghana 


\section{Introduction}

From the beginning of creation until now the existence of both individuals and communities have often been confronted with challenges that easily surmount not only their individuals' strength but also their local capabilities to manage and handle them. Currently, with uncertainties and massive risks associated with our natural settings, these problems are still faced by mankind and public managements at different levels often have to find mechanisms to address them. For example, these days, it is not uncommon to witness the occurrences of disasters like floods, droughts, wild fires, pests and pestilences, epidemics, earthquakes, and hurricanes. According to UNEP (2004), despite the fact that most of these catastrophes could be attributed to natural incidences, a number of them are usually instigated by human beings. Regrettably, the pecuniary costs of these natural disasters in recent times and the number of human lives that have been affected have been myriad (UNEP, 2004; UN/ISDR (2009). Globally, available evidence from World Disaster Report, (2018) based on Emergency Events Database (EM-DAT) demonstrated that from the period between 1994 and 2013, there were 6,873 natural disasters worldwide and this led to the loss of 1.35 million lives. This implies that on average approximately 68,000 lives each year were lost. In general, these, significantly, on average had an effect on 218 million people per annum during this 20 -year period. EM-DAT data also indicate that flooding caused the greater part of disasters between 1994 and 2013, accounting for 43\% of all recorded events and affecting almost 2.5 billion people. This was followed by storms killing more than 244,000 people and costing US\$936 billion in recorded damage. The third most popular type of disaster was earthquakes (including tsunamis) which claimed more people than all other types of disaster put together, killing about 750,000 people between 1994 and 2013.

In all these crises situations, recent national events have indicated that Ghana has not been spared from the socio-economic and the depressing developmental ramifications of disasters. For instance, in June $3^{\text {rd }} 2015$, in the middle of Ghana's capital, Accra, the public witnessed a historic flash flood event, together with an explosion at a Goil filling station that ended up the lost of more than 152 lives (Asumadu-Sarkodie, Owusu, \& Rufangura, 2015). In addition, in 2009, in the Northern sector of Ghana, eight lives were lost, 121,000 people were displaced and a total of about 30,000 hectares of farmland were destroyed as a result of floods (Kunateh, 2009).In essence, the sheer scale of devastations to the nation due to natural and manmade disasters both in urban and rural areas in the developing countries like Ghana cannot be belittled. Accordingly, in the face of these challenges, various stakeholders have come to accept that in order to accomplish a sustainable development, it is essential that all levels of the society must participate in finding viable answers to the problems. This has called for building an open society that welcomes pluralism, innovative ideas and a development strategy that have the potential to be executed more openly, broadly and with continual dialogue among the various public actors (Moulaert, MacCallum, Mehmood, \&Hamdouch, 2013). In view of this, over the past two decades, inter-organizational collaboration among those involved in providing human services both public and private has significantly improved to the point where collaborative measures among various organizations have become one of the crests of the new millennium strategies (Longoria, 
2005; Heath, 2007). As a result of this, the traditional boundaries between various organisations have become unclear, with less direct duties for governments and broader governance duty for business and civil society (Mangoyana, Robert \& Collits, 2014). The implication here is that the inter-organizational collaboration is presently playing a major role in most countries' development agenda propelled by the need to jointly assemble and effectively employ assets and resources to accomplish self-reliance and sustainable growth (Torres-Rahman, Baxter \& Rivera; 2015).

At the core of all these significant opportunities for long lasting and major solutions that inter-organisational collaboration potentially bring, public sector managers, are also still confronted with a critical strategic decision as to whether to undertake assignments alone or in collaboration with other organizations (O'Leary \& Bingham, 2009). For the academic world to comprehend how this dilemma is overcome, several academics such as Bardach (1998); Bryson, Crosby \& Stone (2006); Thomson \& Perry (2006) have focused on the determinants of collaboration. Moreover, in the last decade, efforts are being made to provide empirical backing on the factors contributing to inter-sectoral collaboration amongst public organisations (Krueathep, Riccucci \& Suwanmala 2010; McGuire \& Silvia 2010; Mullin \& Daley 2010). These researchers have examined explanatory factors like resource dependency, task complexity, and problem severity. However, while the previous management study has focused solely on intra-organizational means of tackling disasters, the most outstanding shortfall in these studies is the abandonment of the demographic characteristics of public managers (Esteve, Boyne, Sierra \&Ysa, 2012). In essence, not much consideration has been given to the demographic characteristics of public managers and how they affect their commitment to inter-sectoral collaboration. Meanwhile, available evidence has shown that each demographic feature, from the perspectives of the experts like Ansell \& Gash (2008), and Hambrick \& Mason (1984), can have significant impact on how the top managers are ready to commit to inter-organisational collaboration and as such can be relied upon to envisage an organization's attitude towards the management of issues like disasters. According to Kwon \& Banks, (2004), demographic variables: gender, age, marital status, educational qualifications, as well as job tenure, play an important role in understanding the commitment of any group of professionals in the world of work.

However, in spite of the general acknowledgement, most of these researches have focused on the developed world and few of such studies have been conducted in sub-Saharan Africa (Amangala, 2013). Consequently this has led to paucity of information on the relationship between demographics and district managers' commitment to inter-organizational collaboration during disasters' management in Ghana. This has warranted the present study to offer empirical evidence in order to contribute to the commitment-demographic relationship literature in the context of Ghana. The paper therefore aims at examining the influence of demographics on district managers' commitment to inter-organizational collaboration during disasters' management in Ghana.

On the basis of above study aim, the remainder of this paper is organized as follows: The significant of the study will be considered followed by the discussion on the literature review. This involves explanations of concepts of disaster and organisational commitment. Also, the 
relationship between demographics and its relationship with commitment as well as Inter-organisational collaboration and disaster management will be discussed. This will be followed by the research methodology which will involve in detail the data collection method and analytical procedures. Finally the research findings and conclusions together with the discussion on the main implications on disaster management in Ghana will be presented.

\section{The significance of the study}

This study is significant in that for some time now the problems facing various governments in Africa have become multifaceted and as such the trans-boundary character of certain crises or disasters create problems that cannot be solved by a single organization alone. Taking into account such situations, having the understanding of better determinants for inter-organisational collaboration can be very important information for local stakeholders to have high qualities personnel that can have better capabilities in managing crises during disaster times. This is because the various stakeholders will become aware of the extent of influence that the demographic factors have on individual's commitment to it. It is therefore believed that the results of the study will offer the district managers pertinent information for making effective strategic plans in addressing disaster management problems in the various districts in Ghana.

Secondly, by providing better demographic determinants of inter-organisational collaboration, various local governments will have good idea about the nature of district managers who need to be considered if they want to deal with disaster at the local level. Consequently, such information would help facilitate in solving local crisis caused by disasters.

\section{Literature review}

\section{The concept of disaster}

Throughout the literature it is noted that the concept of disaster is variously defined and a few of these definitions can be considered. From the Oxford dictionary, a disaster is a sudden accident or a natural catastrophe that causes great damage or loss of life, while the WHO (2012) sees a disaster as an incidence unsettling the usual situations of existence and bringing about a level of misery that goes beyond the capability of the affected community to adjust. Anderson, (2000), also opined that the term "natural disaster" is used in reference to an incident or situation that overpowers the society and local skills to manage and even address them. Examples of these natural disasters in the context of Ghana include floods, droughts, wild fires, pests and pestilences, collapse of buildings and epidemics like AIDS. According to UNEP, (2009), although most of the occurrences of these disasters could be ascribed to natural causes, many of them are man-made. In view of this, El-Masari \& Tipple (2002) consider disasters as "failures of development" (p.162) as policy makers have often disregarded to effectively incorporate development primacies with environmental concerns. This assertion is valid due to the fact that the inability on the side of the government to safeguard the actual implementation of regulation policies on, for example, buildings, has intensified citizens' vulnerabilities in a lot of developing countries. In the course of disasters, the task of the government as collaboration requires is to provide both material goods and 
services in their management which comprise the improvement of the institutional and human capacities, early warning signals, technical expertise, enforcement of law on building policies, and education of the people on disaster mitigation and preventive measures (Pandey \& Okazaki, 2005). Thus, general management of disaster is usually about putting together and controlling resources in order to produce competencies that can help to cope with a disaster when it does occur (Ödlund, 2010). For a long time now, Pierson \& Clair (1998) have argued that the individual management practices, nonetheless, should not be limited to managing the outcomes ex post facto, but to a large extent, individuals are supposed to be seen to be averting disasters and getting ready the institutions for coping with them before and during the manifestation of the incident. At the time of a disaster, experts like Berthod, Müller-Seitz \& Sydow, (2013) have noted that there are generally limitations on the institutional structures and human endeavours that often pave way for animosities, particularly among public sector institutions that struggle for inadequate amount of resources in their attempt to handle numerous institutional obligations. The resultant tussles for insufficient resources regularly cause two key effects such as working against effective disaster management and putting the well-being of the general public as well as major possessions within the society at risk (Berthod, Müller-Seitz \& Sydow, (2013).

In Ghana, in trying to control and manage natural disasters, the government has put in place the National Disaster Management Organization (NADMO) which was established by Act 517 of Parliament in 1996. Its directives have been to draw of plans to prevent disasters and or mitigate their effects on the people, to coordinate activities before and during emergencies as well as ensuring post- disaster rehabilitation, reconstruction and resettlement (NADMO Annual Report, 2010). Since its establishment, NADMO has instituted a system of decentralisation as an instrument in the discharge of its duties. Structurally, there are a number of risk minimisation platforms at various levels which include: national, regional, metropolitan, municipal and district (NADMO, 2005).

\section{Organisational Commitment}

In general while the concept of organisational commitment has been popular in recent times, a collective agreement on what commitment is has been deficient (Meyer \& Herscovitch, 2001).For example, as far as back 1970, Porter \& Smith, (1970), (as cited in Mowday, Steers, \& Porter 1979), see organisational commitment as "the relative strength of an individual's identification with and involvement in a particular organisation" (p. 226). Equally, Brown (1996) asserted that organisational commitment meant the type of dedication to and support of the organisation that goes beyond mere job expectations and payments and rewards. In the same way, Johns \& Saks, (2005) assert that organisational commitment can be considered to be an approach that reflects the power of relations between an organisation and its workforces, or the extent to which a worker is keen to serve his or her organisation. This is in consistent with Porter, Steers, Mowday, \& Boulian (1974) account of organisational commitment which is considered as "a strong belief in and acceptance of the organization's goals, a willingness to exert considerable effort on behalf of the organization, and a definite desire to maintain organizational membership" (p. 604). This definition was corroborated by Allen and Meyer (1996) who expounded on this definition stating that organizational commitment normally is 
a psychological link between the employee and his or her organization that makes it less likely that the employee will leave the organization. The idea here is that organisational commitment can be seen as a psychological state that binds the individual to the organization as perceived by many researchers (Mathieu \& Zajac, 1990; Meyer \& Allen, 1996; Morrow, 1993, as cited in Fornes et al., 2008).

Meyer and Allen (1991) suggest that employees usually develop three categories of commitment to their organization namely: affective, continuance, and normative.

With the affective commitment, it is explained that it is the degree to which employees are engaged in, and have emotional connection to their organization due to the fact that they recognize and accept their organisational goals and values. Meyer et al. (1993) have claimed that the employees that remain in their organisations with an irrepressible affective commitment preserve their positions, not only because they need to keep their jobs, but also because they have the desire to have them. In a essence with this type of commitment, there exists a positive connection between the individual employees and the organisation, since the two have comparable values (Sezgin 2009). In a way, affective committed employees continuously work for their organisation willingly and zealously.

With regards to normative commitment, Meyer et al. (1993) assert that such commitment demonstrates employees' sense of debt to their organisations. Employees with this type of commitment will stay with their organisations as a result of their belief that it is the "right and moral" thing to do (Meyer and Allen 1991). Normative commitment is likely to grow when employees feel devoted to their employers or obliged to work for the exceptional rewards that they receive from their organizations. Employees who have sturdy normative commitment do not easily leave their organisations, but rather stay with them and are always willing to compensate for the special treatments obtained from the organization for the reason that they feel they "ought to"(Meyer et al. 1993).

In the case of continuance commitment, (Meyer et al. 1993) opined that it is linked to any type of experience that employees might have had and what employees might have given to their organisations. With this commitment, Joolideh \&Yeshodhara (2009) have argued that employees often find it hard in "giving it up" and an unknown "opportunity cost" in leaving the organization. Employees with strong continuance commitment stay with their organisations predominantly to circumvent the costs of leaving.

In the context of this study, commitment embodies all the three categories discussed above and it can be seen as self-imposed preparedness by the employees (i.e, district managers) with will power and enthusiasm to contribute to the accomplishment of the organisational goals through its association with other organisation.

\section{Inter-organizational collaboration and disaster management}

The concept of collaboration has been variously defined by experts. For example, Wood \& Gray, (1991) consider collaboration to take place "when a group of autonomous stakeholders of a problem domain engage in an interactive process, using shared rules, norms, and structures to act or decide on issues related to that domain" (p. 146). Graham \& Barter, (1999) also consider it as "a relational system in which two or more stakeholders' pool together 
resources in order to meet objectives that neither could meet individually" (p. 7). In the context of inter-organizational collaboration, O'Leary \& Vij, (2012) also have the view that the concept can be understood as 'any joint activity by two or more agencies working together that is intended to increase public value by their working together rather than separately' ( p. 508). The idea here is that inter-organisational collaboration can be characterised as win-win situations for all interested parties and well-defined relations between two or more organisations who have the goal of achieving collective goals (Mattessich, Murray-close \& Monsey, 2001; Payan, 2007).

In essence, inter-organisational collaboration has a positive effect on the management of disasters. This assertion is based on the idea working alone in solving natural disasters like floods will be an exercise of futility. The reasons for this argument are varied. Amongst them is the fact that the recent trans-border features of some of the disasters like bush burning, floods, etc. have produced socio-economic problems that make it difficult for only one organisation to handle and to manage on its own. With these problems, a number of experts have generally referred them as "indivisible" for a single organisation (Aldrich \& Pfeffer, 1976; Gray 1985) as disasters create environments which demand collaboration. Secondly, due to the multifaceted nature of contemporary disasters which are likely to bring about unexpected hardship on organisations, traditional ways of managing the tasks by a single organisation are likely not to be suitable to successfully respond to the problems that often spring up (Austin, 2000; Page, 2003). Considering such situations, inter-organisational collaboration has been considered by number of organisations as a problem solving approach which relies on the strengths of each organisations to effectively manage disasters (Edwards, 2009). Last but not the least, inter-organisational collaboration can be seen to have the potentials of reducing risk of fragmentation of performance of organisations during disasters. Inexplicitly, inter-organisational collaboration has the potential to succeed in coordinating affairs and achieving cooperation through the sharing of resources amongst individual organisations and reducing such a risk of failure in managing disasters (Fjeldstad, Snow, Miles, \& Lettl, 2012).

\section{Research Methodology}

This was a descriptive quantitative study with cross sectional study design used to investigate the phenomenon. The study area was the whole of Ashanti region and the population size for the study was 195 district managers. Due to the small nature of the population size, the sample size was considered to be the same as the population hence the census method was used. This implies that all the public sector managers at the district levels were selected to be involved in the study. In terms of instrument, the data collection technique included not only physically distributed questionnaires but also online surveys, although the former method was the overriding one.

Two types of questionnaires were used in this study. The first questionnaire was a general one, aimed at gathering crucial information on the common demographic characteristics of the respondents which, in the context of this study included: gender, age, educational qualification, marital status and tenure. The second questionnaire was to determine managers' commitment on a standard 5-point Likert Scale, with 1 being "strongly disagree" and 5 being 


\section{Macrothink}

Journal of Public Administration and Governance

ISSN 2161-7104

2020, Vol. 10, No. 1

"strongly agree". The reliability of the items was estimated using Cronbach Alpha with an estimated value of 0.878 and since it was more than 0.7 , these items were maintained.

The distributed questionnaires across the study area had a response rate of $87 \%$, (that is, 170 managers responding to the questionnaires) with only $13 \%$, non-response rate. The data in this study were entirely analyzed using SPSS software (Version, 21). In analysing the data, descriptive frequencies, analysis of variance one-way ANOVA and independent T-test together with the Pearson's correlation analysis were employed to present the study results. Additionally, to further understand the extent of the influence that the demographic factors have on managers' commitment to inter-organisational collaboration the regression tool was performed. From the bivariate analysis, the demographic variables used were: educational qualifications, age, gender, tenure, and marital status

\section{Results and Discussion}

\section{Socio-Demographic Characteristics of Respondents}

The demographic characteristics of respondents were in relation to gender, age, marital status, educational level, and length of service. The results obtained in relation to socio-demographic characteristics of the respondents are shown in Table 1.

Table1. Background Information of Respondents

\begin{tabular}{lcc}
\hline Variable & Frequency & Percentage (\%) \\
\hline 1. Gender & 107 & 62.9 \\
Male & 63 & 37.1 \\
Female & & \\
2. Age & 27 & 15.9 \\
21-30 years & 52 & 30.6 \\
31-40 years & 33 & 19.4 \\
41-50 years & 58 & 34.1 \\
51years and above & & \\
3. Marital Status & 30 & 17.6 \\
Single & 140 & 82.4 \\
Married & & \\
4. Academic Qualification & 3 & 1.8 \\
Below Diploma & 19 & 11.2 \\
Diploma & 92 & 54.1 \\
First Degree & 56 & 32.9 \\
Second Degree & & \\
5. Length of Position held & 10 & 5.9 \\
Less than 1year & 29 & 17.1 \\
1-5 years & 70 & 41 \\
6-10 years & 28 & 16.5 \\
11-15years & 33 & 19.4 \\
61 years and above & & \\
\hline
\end{tabular}

Source: Field work, Owusu (2019) N=170

Table I provides frequencies of the demographic characteristics of respondents which were in relation to gender, age, marital status, educational level, and tenure. The results obtained in relation to socio-demographic characteristics of the respondents indicated that there were a total of 170 respondents. Out of this figure, 107 (62.9\%) were males and $63(37.1 \%)$ were 
females. This implies that the district management in the public sector is male dominant, which is not amazing in the context of Africa as majority of the higher positions are male dominated fields. In terms of age, majority of the respondents were from 51 years and above with a total number of $58(34.1 \%)$. This was followed by those at the age group of 31-40 years with a number of $52(30.6 \%)$. The third largest age group was those in 41-50 years with a number of $33(19.4 \%)$. Considering the statutory retirement age of 60 years for workers in Ghana, it could be said that many of the respondents were nearing their retirement age. This is could be beneficial to the local management as the young can, not only learn from those with experiences but also it would make succession plan relatively easier. In terms of marital status, majority of the respondents with a number of $140,(82.4 \%)$ were married while 30 $(17.6 \%)$ were single. The small number of people who were single is not anything shocking as most Ghanaian get married earlier in life once they start working. So it could be that these singles (30) were those who were widows/widowers, in relationship but not traditionally married or divorced. In the case of education, majority $92(54.1 \%)$ of the respondents was mostly bachelor's degree holders. Besides, those with the second degree were the second highest, 56 (32.9\%) while those with a diploma 19 (11.2\%) were the third highest. The least was those under diploma (i.e; Senior Secondary School/Middle Leaving Certificate holders) with a number of only $3(1.8 \%)$. Finally, with respect to tenure, more than half of the respondents, $70(41 \%)$ have worked between 6 and 10 years. This was followed by those who have worked for 16 years and above, 33 (19.4\%) whilst those with 1-5 years of work experience $29(17.1 \%)$ were the third highest of the respondents. The fourth largest group was those with 11-15 years of experience and these were 28 (16.5\%). The least group was those with only less than 1 year of work with the number of $10(5.9 \%)$. The idea is that the local district managers are endowed with a lot experiences and as such those minority group without experience are likely to benefit from them.

\section{Study Results of the main research question}

The main research question of this study was: " to what extent do demographic factors influence district managers' commitment to inter-organisational collaboration during disasters' management in Ghana?"

In answering the question, the one-way ANOVA and T-test were first employed. One-way ANOVA assesses the mean of one or more groups based upon independent demographic variables such as age, tenure and level of education. On the other hand, T-test is usually used to evaluate the difference in the means between two groups and in the current study the variables are gender and marital status as shown in table 2 below.

Table 2. One-Sample Test

\begin{tabular}{|c|c|c|c|c|c|c|}
\hline & \multicolumn{6}{|c|}{ Test Value $=0$} \\
\hline & \multirow[b]{2}{*}{$\mathrm{t}$} & \multirow[b]{2}{*}{$\mathrm{df}$} & \multirow{2}{*}{$\begin{array}{c}\text { Sig. } \\
\text { (2-tailed) }\end{array}$} & \multirow{2}{*}{$\begin{array}{c}\text { Mean } \\
\text { Difference }\end{array}$} & \multicolumn{2}{|c|}{$\begin{array}{l}\text { 95\% Confidence Interval of } \\
\text { the Difference }\end{array}$} \\
\hline & & & & & Lower & Upper \\
\hline Gender & $\begin{array}{r}36.89 \\
2\end{array}$ & 169 & 0.000 & 1.371 & 1.30 & 1.44 \\
\hline Marital status & 40.119 & 169 & 0.000 & 1.176 & 1.12 & 1.23 \\
\hline
\end{tabular}


Source: Field work, Owusu (2019)

With the analysis of the two variables (gender and marital status), the empirical results of the study revealed that first, there was statistically significant difference between male and female (gender) with $\mathrm{T}$-test $=36.892, \mathrm{p} \leq 0.05$ ). The female district managers have less commitment to inter-organisational collaboration (Mean $=2.52, \mathrm{SD}=0.965$ ) than male district managers who have higher commitment to inter-organisational collaboration (Mean = $3.01, \mathrm{SD}=1.06$ ) during crisis response management. Similarly, with the marital status, there was also statistically significant difference between respondents who were married and those who were single in terms of their commitment to inter-organisational collaboration with T-test $=40.119, \mathrm{p} \leq 0.05)$. In terms of commitment, the study found out that those who were married were more committed to inter-organizational collaboration (Mean $=3.86, \mathrm{SD}=$ 1.056), in contrast to those singles who were less committed (Mean $=2.70, \mathrm{SD}=1.022$ ).

\section{Analysis of variance (ANOVA) with age group, tenure and level of education}

The results of differences in commitment related to the values of inter-organizational collaboration were analyzed with, one-way analysis of variance (ANOVA, see Table 3). The results indicated that that there was statistically significant difference between subgroups' of respondents' (district managers) commitment to inter-organizational collaboration. From the table it can be noted that there is statistically significant difference in respondents' characteristics such as educational level, tenure and age group with the following respective results: $\mathrm{F}(3 ; 167)=5.111, \mathrm{p} \leq 0.05) ;, \mathrm{F}(3 ; 167)=3.264, \mathrm{p} \leq 023) ; \mathrm{F}(3 ; 167)=4.905, \mathrm{p} \leq .003)$.

In determining the differences in commitment among the various age groups of district managers, a descriptive test was also performed. Per the descriptive results, it was revealed that the age group of 51 years and above had the highest commitment (mean=3.17, $\mathrm{SD}=$ 1.028 ) followed by the age group of $41-50$ years $(\mathrm{Mean}=2.91, \mathrm{SD}=1.100)$. The age group of $30-40$ years came in the third position (Mean $=2.70, \mathrm{SD}=0.993)$ and the last group was those between the years of 21-30 (Mean=2.46, SD=0.959). In effect, the elder managers were more committed than the younger ones in terms of inter-organisational collaboration during disasters' management in Ghana.

Table 3. ANOVA with age group, tenure and level of education

\begin{tabular}{|l|l|r|r|r|r|r|}
\hline \multicolumn{2}{|c|}{} & $\begin{array}{c}\text { Sum of } \\
\text { Squares }\end{array}$ & df & $\begin{array}{c}\text { Mean } \\
\text { Square }\end{array}$ & \multicolumn{1}{c|}{ F } & Sig. \\
\hline \multirow{3}{*}{$\begin{array}{l}\text { Educati } \\
\text { on }\end{array}$} & Between Groups & 6.878 & 3 & 2.293 & $\begin{array}{r}5.11 \\
1\end{array}$ & .002 \\
\cline { 2 - 7 } & Within Groups & 74.469 & 167 & .449 & & \\
\cline { 2 - 7 } & Total & 81.347 & 170 & & & \\
\hline \multirow{4}{*}{ Tenure } & Between Groups & 9.144 & 3 & 3.048 & 3.26 & .023 \\
& Within Groups & 155.003 & 167 & .934 & & \\
\cline { 2 - 7 } & Total & 164.147 & 170 & & & \\
\hline \multirow{2}{*}{$\begin{array}{l}\text { Age } \\
\text { Group }\end{array}$} & Between Groups & 16.647 & 3 & 5.549 & $\begin{array}{r}4.90 \\
5\end{array}$ & .003 \\
\cline { 2 - 8 } & Within Groups & 187.800 & 167 & 1.131 & & \\
\cline { 2 - 8 } & Total & 204.447 & 170 & & & \\
\hline
\end{tabular}


Source: Field work, Owusu (2019)

With regards to the tenure, similar to the age groups, it was revealed that those who had worked 16 years and above had the highest commitment (Mean=3.24, $\mathrm{SD}=1.001$ ). This was followed by those who had worked for the years between 11 and 15 (Mean= 2.86, SD= 0.932). Those with the working years experience between 6 and 10 were in the third position (Mean= 2.75, SD=1.142) and the last group was those who had worked the least years between 1and 5. (Mean= 2.55, $\mathrm{SD}=0.827$ ). Thus, those with more experiences were more committed than those with less experience when it comes to inter-organisational collaboration during disasters' management in Ghana.

When it comes to the educational levels, the results were not different as there were differences among the educational groups. Explicitly the outcomes showed that those with the highest degree (that is $2^{\text {nd }}$ degrees) were more committed (Mean $=2.96, \mathrm{SD}=0.934$ ). The next committed group was those with First degree (Mean=2.88, $\mathrm{SD}=1.088$ ), followed by those with diploma (Mean=2.32, $\mathrm{SD}=0.946$ ). The least committed group were those who were below Diploma (Mean= 2.01, $\mathrm{SD}=1.732$ ). The idea here is that the higher the educational level of the district manager the higher the level of commitment to inter-organisational collaboration during disasters' management in Ghana.

\section{Demographic factors and their influence on district managers' commitment to inter-organisational collaboration using Pearson's correlations}

The level of influence that the various demographic variables (gender, age, education, tenure and marital status) have on the district managers' commitment to inter-organisational collaboration during disasters' management in Ghana was also assessed with Pearson's correlations. Based on the analysis, the study results uncovered that age $\left(\rho=0.235^{* *}\right.$, $\mathrm{p} \leq 0.002)$, education $\left(\rho=0.181^{* *}, \mathrm{p} \leq 0.018\right)$, and tenure $\left(\rho=0.207^{* *}, \mathrm{p} \leq 0.007\right)$ all had significant positive influence on district managers' commitment to inter-organisational collaboration in Ghana. The same applies to gender $\left(\rho=.224^{* *}, p \leq 0.003\right)$. However, marital status ( $\rho=-.057^{* *}, p>0.458$ ) has negative influence on district managers' commitment to inter-organisational collaboration. This means marital status has the potential to reduce district managers' commitment

\section{Regression Analysis}

In order to understand the magnitude of the influence that the various demographic factors have on the district managers' commitment to inter-organisational collaboration during disasters' management in Ghana, the regression analysis was performed. From the analysis, the results of the regression were varied as depicted in table 4 . 
Table 4. Summary of Level of Prediction of Independent Variables on Dependent Variables

\begin{tabular}{|l|r|r|r|r|r|}
\hline $\begin{array}{l}\text { Mode } \\
1\end{array}$ & Variable & \multicolumn{1}{|c|}{$\mathrm{R}$} & \multicolumn{2}{|c|}{$\begin{array}{c}\text { Adjusted R } \\
\text { Square }\end{array}$} & $\begin{array}{l}\text { Std. Error of } \\
\text { the Estimate }\end{array}$ \\
\hline 1 & Tenure & $.207^{\mathrm{a}}$ & .043 & .037 & 1.030 \\
\hline 2 & Age Group & $.235^{\mathrm{a}}$ & .055 & .050 & 1.023 \\
\hline 3 & Education & $.181^{\mathrm{a}}$ & .033 & .027 & 1.035 \\
\hline 4 & Marital Status & $.057^{\mathrm{a}}$ & .003 & -.033 & 1.051 \\
\hline 5 & Gender & $.224^{\mathrm{a}}$ & .050 & .045 & 1.026 \\
\hline
\end{tabular}

a. Predictors: (Constant), Tenure, Gender, Age Group, Education and Marital Status

Source: Field work, Owusu (2019)

The table 5 above revealed a summary of degree of the influence that the various demographic factors have on the district managers' commitment to inter-organisational collaboration level of From the table it can be observed that $3.7 \%$ of the managers' commitment to inter-organisational collaboration can be positively explained by tenure, while age group contributes to $5 \%$. The educational qualification also positively explains $2.7 \%$ of managers' commitment, whereas in similar way $4.5 \%$ of manager's commitment to inter-organisational collaboration can be explained by Gender. However, marital status contributes negatively $3.3 \%$ of managers' commitment to inter-organisational collaboration.

Using multi-regression analysis to demonstrate significant position of combined relationship of demographic variables and district managers' commitment to inter-organisational collaboration, the result had a positive result as it can be seen in Table 5.

Table 5. Model Summary of regression analysis of joint relationship of demographic variables

\begin{tabular}{|l|r|r|r|r|}
\hline Model & R & R Square & Adjusted R Square & \multicolumn{2}{|c|}{$\begin{array}{c}\text { Std. Error of the } \\
\text { Estimate }\end{array}$} \\
\hline 1 & $.384^{\mathrm{a}}$ & .148 & .126 & .983 \\
\hline
\end{tabular}

a. Predictors: (Constant), Tenure, Education, Gender, Age Group, Marital status

Source: Field work, Owusu (2019)

From the table it can be concluded that putting all the variables together, there is a combined significant influence of the independent variables (Tenure, Education, Gender, Age Group, Marital status) on the commitment of the district managers' commitment to inter-organisational collaboration. In general it can be said that the significant adjusted $\mathrm{R}$ Square value of 0.126 explains that $13 \%$ of managers' commitment to inter-organisational collaboration is explained by the demographic factors. The rest are explained by factors that are not part of this study. 


\section{Discussion}

This study has focused on demographics and district managers' commitment to inter-organisational collaboration during disasters' management in Ghana. The results have revealed that the extent of inter-organisational collaboration was influenced positively by gender, tenure of office, age and educational qualifications whilst it was negatively influenced by district managers' marital status. These results are not coincidence as they support the existing literature. For example, in the case of gender, male were found to be more committed to inter-organisational collaboration during disasters' management and this could be attributed to the culture of trust in Ghana (Affum-Osei, Acquaah, \& Acheampong, 2015). This is so because, women in Africa and for that matter Ghana do not easily associate with people that they do not know very well and therefore have little or no trust in them. Unlike the male counterpart who are risk takers, women are traditionally risk averse and therefore will hesitate to take the risk of associating or collaborating with people they do not know especially with male counter parts. Thus this assertion is in line with the argument made by Ngo, Wing, \& Tsang, (1998) (cited in Kónya1, Matić, \& Pavlović, 2016) that the cultural setting has the potential to determine the degree of the impact of gender on organisational commitment in a way and manner that if women are open to the elements of sex unfairness. This situation, in a certain circumstance, has the possibility of having an adverse effect on their organisational commitment. In effect in times of disasters, women would only like to take the risk of collaborating if only they trust the colleagues that they are likely to work with. In fact in Ghana, culturally, women are not supposed to have a sudden relationship with a male counterpart unless they have long time family or blood relationship. This means that during disasters committing to any form of relationship just to solve a disaster problem is not something a female head of organisation will be ready to do even if it is the best option because of the fear societal misinterpretation of such an action. Besides, in Africa, the gender model plays a greater part in explaining why the females are less committed to inter-organisational collaboration during disasters' management. According to the proponents of this model, Aven, Parker, \& McEvoy, (1993) women have their greater role in family and thus have a lower level of commitment to the organisation. This model further claims that "women accept family roles as a chief source of their identity and fulfillment, leading to a different orientation to work for men, for whom work is paramount" (Loscocco, 1990, p. 155).

In terms of marital status, it was found out that those were married were more committed to inter-organizational collaboration during disasters' management in Ghana than those who were not married. This finding can be explained based on the fact that those who are married will not be afraid to trust a stranger and therefore will be more comfortable in associating themselves with other organisational heads even if they do not know each other them compared to those who are not married (Choong, Tan, Keh, Lim, \& Ta, (2012). The fundamental explanation is that under normal circumstance those who are married often have more stable job, due to their assumed experience and also have trust in people and therefore are willing to commit to them than those who are singles. Also an argument made by Popoola (2009) supports this assertion because according to the author, in times of disasters the 
married people will be willing to collaborate with other organisations to manage the disasters for fear of losing their position and or job, especially if that disaster is to affect their job. This is in line with the study of Ali \& Zafar (2006) in Pakistan which pointed out that married employees were more committed than employees who were singles and therefore not married. Also, Affum-Osei, Acquaah \& Acheampong (2015) in their research in Ghana also realised that married people were more committed than those who were not married.

In the case of tenure, the study found that those with more experiences were more committed than those with less experience. This is consistent with time job model which asserts that commitment is achieved out of work-experience. Due to their experience, senior managers will have both emotional, continuance and or normative commitments which will give the managers' sense of debt to their organisations (Meyer \& Allen, 1991). With these types of commitments, particularly normative, managers will commit themselves in solving the disaster problem by collaborating with other organizations as a result of their belief that it is the "right and moral" thing to do (Meyer \& Allen 1991). In recent times, a study by Khurshid \& Fauzia (2015) among college teachers in Islamabad confirmed this claim. This is because the outcome of the study showed that employees who were employed for longer years had higher organisational commitment. Similarly, de los Santos \& Not-Land, (2006) also found out that there was a significant connection between work tenure and organisational commitment in their cultural context. Much in the same way, Pala, Eker, \& Eker, (2008) discovered that years in occupation and meaning of the position in the organisation were all associated to organisational commitment among health care workers in Turkey.

In respect to age, the elder managers were found to be more committed than the younger ones. This result corroborates the studies by Devos, \& Rosseel, (2009) who found that age is positively related to commitment and that older employees are more committed than the younger ones who are mostly new in an organisation. In the same way, the studies of Jena (2015); Igbeneghu \& Popoola (2010) indicated that there was undoubtedly a substantial connection between age and organisational commitment.

Finally the study found out that the higher the educational level of the district manager the higher the level of commitment to inter-organisational collaboration during disasters' management in Ghana. These differences can be explained by the levels of confidence and trust that those with higher level of education have in themselves and their ability to deal with problems that emanate from behavioural conduct of people who are not known to them (Loscocco, 1990; Meyer \& Allen, 1997; Akintayo 2010). According to Akintayo (2010), compared to those who are less qualified, highly qualified employees are often seen to be more committed due to their alertness to the organisational positive attitudes towards those who are seen to be the organisational assets. Such better treatment of more qualified employees makes them enjoy security, opportunities, and comfort in the organisation and as such they are more prepared to commit themselves to any collaboration that is likely to help solve problems like natural disaster (Salami, 2008).

\section{Conclusion}

The purpose of this study has been to examine the demographics and district managers' 
commitment to inter-organizational collaboration during disasters' management in Ghana. The study findings have indicated that the level of commitment of district managers to inter-organisational collaboration during disasters' management in Ghana cannot equally be affected by only availabilities of resources. Instead, the degree of commitment is dependent upon the susceptibility of the involved district managers, which can and regularly does logically differ across educational qualifications, age, gender, tenure, and marital status

This finding has the policy implication which demands appropriate actors to consider beyond technical fixes in addressing natural disasters. Indeed, the basic cultural, educational, social, and economic patterns that bring about a low level of commitment of people like women and thereby create their particular vulnerability to natural disasters are difficult to handle only by economic means alone. Instead, the study finding implies that policymakers, nongovernmental organisations, and the academic community need to pay closer attention to, for instance, the gendered nature of disaster vulnerability. Such attention should not only concentrate on the special medical, economic, and security needs of the susceptible district managers and the inhabitants of their districts, but also the mechanisms to ensure equal and unbiased allocation of relief resources. Developing such policies will help in putting a stop to the unfavourable effect of large-scale natural disasters on those who are vulnerable in societies where their daily socioeconomic status is inadequate. With such policies, the excess disaster mortality rate of the vulnerable will potentially be reduced.

Thus, while resources may be needed during disaster's management, the finding of this study in the context of Africa suggests that for organisational managers to be able to manage disaster by collaborating with other organisations there is the need to understand the extent of their long term trust that they have for each other. In Africa and for that matter Ghana, the preparedness of the various organisations to make contributions in terms of resources, equipment, knowledge and capabilities in a combined effort not only depends on the availability of the resources but also the trust for each other. The idea here is that managing higher level of familiarity and trust in Africa is very important in ensuring inter-organisational collaboration which can lead to addressing socio-economic problems during disaster. This is because with better collaboration, organisations will be able to contribute, drum up support and mete out resources amongst themselves more effectively during crisis. It can therefore be concluded that this study has implications for disaster planning, readiness and by and large development of shared efforts in disaster reaction management.

\section{References}

Affum-Osei, E., Acquaah, E., \& Acheampong, P. (2015). Relationship between organisational commitment and demographic variables: Evidence from a commercial bank in Ghana. American Journal of Industrial and Business Management, 5(12), 769. https://doi.org/10.4236/ajibm.2015.512074

Akintayo, D. I. (2010). Work-family role conflict and organizational commitment among industrial workers in Nigeria. Journal of Psychology and counseling, 2(1), 1-8. 
Aldrich, H. E., \& Pfeffer, J. (1976). Environments of organizations. Annual review of sociology, 2(1), 79-105. https://doi.org/10.1146/annurev.so.02.080176.000455

Allen, N. J., \& Meyer, J. P. (1996). Affective, continuance, and normative commitment to the organization: An examination of construct validity. Journal of vocational behavior, 49(3), 252-276. https://doi.org/10.1006/jvbe.1996.0043

Anderson, W. A. (2000). Women and children facing disaster. InManaging disaster risk in emerging economies, ed. A. Kreimerand M. Arnold, 85-90. Washington, DC: World Bank

Ansell, C., \& Gash, A., (2008). Collaborative governance in theory and practice. Journal of Public Administration Research and Theory, 18, 543-571. https://doi.org/10.1093/jopart/mum032

Asumadu-Sarkodie, S., Owusu, P. A., \& Jayaweera, H. M. (2015). Flood risk management in Ghana: A case study in Accra. Advances in Applied Science Research, 6, 196-201.

Asumadu-Sarkodie, S., Owusu, P. A., \& Rufangura, P. (2015). Impact analysis of flood in Accra, Ghana. Advances in Applied Science Research, 6, 53-78.

Austin, J. E. (2000). Strategic collaboration between nonprofits and businesses. Nonprofit and voluntary sector quarterly, 29(1_suppl), 69-97. https://doi.org/10.1177/0899764000291S004

Aven, F. F., Parker, B., \& McEvoy, G. M. (1993). Gender and attitudinal commitment to organizations: A meta analysis. Journal of Business Research. https://doi.org/10.1016/0148-2963(93)90043-O

Bardach, E. (1998). Getting Agencies to Work Together: Th e Practice and Theory of Managerial Craftsmanship. Washington, DC: Brookings Institution Press.

Berthod, O., Müller-Seitz, G., \& Sydow, J. (2015). Out of nowhere? Interorganizational assemblage as the answer to a food-borne disease outbreak. Schmalenbach Business Review. https://doi.org/10.1007/BF03396912

Brown, R. B. (1996). Organizational commitment: Clarifying the concept and simplifying the existing construct typology. Journal of vocational behavior, 49(3), 230-251. https://doi.org/10.1006/jvbe.1996.0042

Bryson, J. M., Crosby, B. C., \& Stone M. M. (2006). The design and implementation of cross-sector collaborations: Propositions from the literature. Public Administration Review, 66, 44-55. Century. Washington, DC: Georgetown University Press. https://doi.org/10.1111/j.1540-6210.2006.00665.x

Chaudhry, N., \& Saini, M. (2014). Impact of Psycho-Demographic Variables on Organizational Commitment in Banking Sector: A Comparative Study. International Journal of Hospitality and Tourism Systems, 7(2).

Choong, Y. O., Keh, C. G., Tan, Y. T., \& Lim, Y. H. (2013). Propensity to Work Abroad Amongst Generation Y Working Adults in Malaysia. World Conferences, 695-705. Penang, Malaysia. 
http://worldconferences.net/proceedings/icssr2013/toc/199\%20-\%20yuen\%20onn\%20

Chowdhury, F. (2015). Demographic Factors Impacting Employee Turnover in the Private Banking Sector of Bangladesh. International Journal of Business and Management Invention, 4(11), 46-54.

Chughtai, A. A., \& Zafar, S. (2006). Antecedents and consequences of organizational commitment among Pakistani university teachers.

Çoğaltaya, N. (2015). Organizational commitment of teachers: A meta-analysis study for the effect of gender and marital status in Turkey. Educational Sciences: Theory \& Practice, 15(4), 911-924.

Cohen, A. (1992). Antecedents of organizational commitment across occupational groups: A meta-analysis. Journal of organizational behavior, 13(6), 539-558. https://doi.org/10.1002/job.4030130602

de los Santos, S., \& Not-Land, E. (2006). Factors related to commitment of extension professionals in the Dominican Republic: Implications for theory and practice. Journal of Agricultural Education, 35(3), 57-63. https://doi.org/10.5032/jae.1994.03057

Dubihlela, J., \& Kupangwa, W. (2016). Influence of selected demographic variables on the adoption and use of electronic business technologies by small and medium-sized retailers. International Journal of Ebusiness and Egovernment Studies, 8(1).

Edwards, P. (Ed.). (2009). Industrial relations: theory and practice. John Wiley \& Sons.

El-Masari, S., \& Tipple, G., (2002). Natural Disaster, Mitigation and Sustainability: The Case of Developing Countries. International Planning Studies, 7(2), 157-175. Carfax Publishing, Taylor and Francis Group, UK. https://doi.org/10.1080/13563470220132236

Esteve, M., Boyne, G., Sierra, V., \& Ysa, T. (2012). Organizational Collaboration in the Public Sector: Do Chief Executives Make a Difference? Journal of Public Administration Research and Theory, 23(4), 927-52. https://doi.org/10.1093/jopart/mus035

Fjeldstad, Ø. D., Snow, C. C., Miles, R. E., \& Lettl, C. (2012). The architecture of

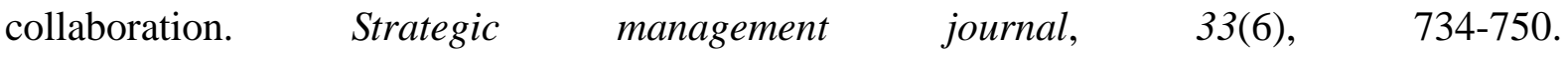
https://doi.org/10.1002/smj.1968

Fornes, S. L., Rocco, T. S., \& Wollard, K. K. (2008). Workplace commitment: A conceptual model developed from integrative review of the research. Human resource development review, 7(3), 339-357. https://doi.org/10.1177/1534484308318760

Geller, F. J., Kuipers, B. S. (2008). Short- and long-term consequencesof age in work teams: An empirical exploration of ageing teams. Career Dev Int, 13, 132-149. Ghanadot.com report of September 28, 2009. https://doi.org/10.1108/13620430810860549

Graham, J. R., \& Barter, K. (1999). Collaboration: A social work practice method. Families in society, 80(1), 6-13. https://doi.org/10.1606/1044-3894.634 
Gray, B. (1985). Conditions facilitating interorganizational collaboration. Human relations, 38(10), 911-936. https://doi.org/10.1177/001872678503801001

Hambrick, D. C., \& Mason, P. A. (1984). Upper echelons: The organization as a reflection of its top managers. Academy of Management Review, 9, 193-206. https://doi.org/10.5465/amr.1984.4277628

Heath, R. G. (2007). Rethinking community collaboration through a dialogic lens: Creativity, democracy, and diversity in community organizing. Management Communication Quarterly, 21(2), 145. https://doi.org/10.1177/0893318907306032

Iqbal, A. (2010). An Empirical Assessment of Demographic Factors, Organizational Ranks and Organizational Commitment. International Journal of Business and Management, 5, 16-27. https://doi.org/10.5539/ijbm.v5n3p16

Jafri, H. (2011). Influence of Psychological Contract Breach on Organizational Commitment. Synergy (0973-8819), 9(2).

Jena, R. K. (2015). An assessment of demographic factors affecting organizational commitment among shift workers in India. Management-Journal of Contemporary Management Issues, 20(1), 59-77.

Johns, G., \& Saks, A. M. (2005). Personality and Learning. Organizational behaviour: Understanding and Managing Life at Work (6th Ed.). Toronto, Canada: Pearson Prentice Hall.

Joolideh, F., \& Yeshodhara, K. (2009). Organizational commitment among high school teachers of India and Iran. Journal of Educational Administration. https://doi.org/10.1108/09578230910928115

Khurshid, F.; \& Parveen, N. (2015). Organizational Commitment in Relation to Biographic Variations Among College Teachers. Journal of Research in Social Sciences-JRSS, 3(1), 96-106.

Konya, V., Matić, D., \& Pavlović, J. (2016). The influence of demographics, job characteristics and characteristics of organizations on employee commitment. Acta Polytechnica Hungarica, 13(3), 119-138.

Krueathep, W., Riccucci, N., \& Suwanmala.C, (2010). Why do agencies work together? The determinants of network formation at the subnational level of government in Thailand. Jounral of Public Administration Research and Theory, 20, 157-185. https://doi.org/10.1093/jopart/mun013

Kunateh, M. A. (2009). Floods displace over 121,000 people in Northern Ghana. A

Kwon, I. G., \& Banks, D. W. (2004). Factors related to the organizational and professional commitment of internal auditors. Managerial Auditing Journal, 19(5), 606-622. https://doi.org/10.1108/02686900410537748

Longoria. (2005). Is inter-organizational collaboration always a good thing? The Journal of 
Sociology and Social Welfare, 32(8), 123-138.

Loscocco, K. A. (1990). Reactions to blue-collar work: A comparison of women and men. Work \& Occupations, 17(2), 152-177. https://doi.org/10.1177/0730888490017002002

Mangoyana, R. B., \& Collits, P. (2014). Collaboration for regional development: A case study of Wide Bay Burnett. Australasian Journal of Regional Studies, 20(3), 430-451.

Mathieu, J. E., \& Zajac, D. M. (1990). A review and meta-analysis of the antecedents, correlates, and consequences of organizational commitment. Psychological bulletin, 108(2), 171. https://doi.org/10.1037/0033-2909.108.2.171

Mattessich, P., Murray-Close, M., \& Monsey, B. (2001). Collaboration: What makes it work? St. Paul, MN: Amherst H. Wilder Foundation.

McGuire, M., \& Silvia, C, (2010). The effect of problem severity, managerial and organizational capacity, and agency structure on intergovernmental collaboration: Evidence from local emergency management. Public Administration Review, 70, 279-288. https://doi.org/10.1111/j.1540-6210.2010.02134.x

Meyer, J. P., \& Allen, N. J. (1991). A three-component conceptualization of organizational commitment. Human Resource Management Review, 1, 61-89. https://doi.org/10.1016/1053-4822(91)90011-Z

Meyer, J. P., \& Herscovitch, L. (2001). Commitment in the workplace: Toward a general model. Human resource management review, 11(3), 299-326. https://doi.org/10.1016/S1053-4822(00)00053-X

Meyer, J. P., Allen, N. J., \& Smith, C. A. (1993). Commitment to organizations and occupations: Extension and test of a three-component conceptualization. Journal of Applied Psychology, 78, 538-551. https://doi.org/10.1037/0021-9010.78.4.538

Morrow, P. C. (1993). The theory and measurement of work commitment. Greenwich, CT: Jai Press.

Moulaert, F., MacCallum, D., Mehmood, A., Hamdouch, A. (2013). General introduction:the return of social innovation as a scientific concept and a social practice. In: Moulaert, F., MacCallum, D., Mehmood, A., Hamdouch, A. (Eds.), The International Handbook on Social Innovation: Collective Action, Social Learning and Transdisciplinary Research. Edward Elgar, Cheltenham, UK and Northampton, USA. https://doi.org/10.4337/9781849809993

NADMO (2005). "Ghana country report and information on disaster reduction", Proceedings of World Conference on Disaster Reduction, National Disaster Management Organization, Kobe, January 18-22.

NADMO. (2010). Annual Report of the National Disaster Management Organization. Accessed at NADMO Regional Office, Tamale, Ghana. 


\section{Mll Macrothink}

Journal of Public Administration and Governance ISSN 2161-7104

Ngo, H. Y., \& Tsang, A. W. N. (1998). Employment practices and organizational commitment: differential effects for men and women?. The International Journal of Organizational Analysis. https://doi.org/10.1108/eb028887

Nifadkar, R. S., \& Dongre, A. P. (2014). To Study the Impact of Job Satisfaction and Demographic Factors on Organizational Commitment among Girls' College, Pune. India Journal of Business Management \& Social Sciences Research, 3, 1-8.

O'Leary, R., \& Bingham, L. B. (Eds.). (2009). The collaborative public manager: New ideas for the twentyfirst

O'Leary, R., \& Vij, N. (2012). Collaborative public management: Where have we been and where are we going?. The American Review of Public Administration, 42(5), 507-522. https://doi.org/10.1177/0275074012445780

Ödlund, A. (2010). Pulling the same way? A multi-perspectivist study of crisis cooperation in government. Journal of Contingencies and Crisis Management, 18(2), 96-107. https://doi.org/10.1111/j.1468-5973.2010.00605.x

Page, S. (2003). Entrepreneurial strategies for managing interagency collaboration. Journal of Public Administration Research and Theory, 13(3), 311-339. https://doi.org/10.1093/jopart/mug026

Pandey, \& Okazaki. (2005). "Community Based Disaster Management: Empowering Communities to Cope with Disaster Risks" United Nations Centre for Regional Development, Japan.

Payan, J. M. (2007). A review and delineation of cooperation and coordination in marketing channels. European Business Review. https://doi.org/10.1108/09555340710746473

Pearson, C. M., \& Clair, J. A. (1998). Reframing crisis management. Academy of Management Review, 23(1), 59-76. https://doi.org/10.5465/amr.1998.192960

Porter, L. W., Steers, R. M., Mowday, R. T., \& Boulian, P. V. (1974). Organizational commitment, job satisfaction, and turnover among psychiatric technicians. Journal of applied psychology, 59(5), 603. https://doi.org/10.1037/h0037335

Porter, L. W., Steers, R. M., Mowday, R. T., \& Boulian, P. V. (1974). Organizational commitment, job satisfaction, and turnover among psychiatric technicians. Journal of Applied Psychology, 59, 603-609. https://doi.org/10.1037/h0037335

Pounder, J. S, \& Coleman, M. (2008). Women-better leaders than men? In general and educational management it still all depends. Leader Organ Dev J, 23, 122-133. https://doi.org/10.1108/01437730210424066

Rabindarang, S., Bing, K. W., \& Yin, K. Y. (2014). The impact of demographic factors on organizational commitment in. 
Salami, S. O. (2008). Demographic and psychological factors predicting organizational commitment among industrial workers. The anthropologist, 10(1), 31-38. https://doi.org/10.1080/09720073.2008.11891026

Sezgin, F. (2009). Relationships between teacher organizational commitment, psychological hardiness and some demographic variables in Turkish primary schools. Journal of Educational Administration. https://doi.org/10.1108/09578230910981099

Thomson, A. M., \& Perry, J. L. (2006). Collaboration Processes: Inside the Black Box. Public Administration Review, 66(1), 20-32. https://doi.org/10.1111/j.1540-6210.2006.00663.x

Torres-Rahman, Z., Baxter, G., \& Rivera, A. (2015). Business and the United Nations. Working Together Towards the Sustainable Development Goals: A Framework for Action. SDG Fund, Harvard Kennedy School CSR Initiative and Inspiris Ltd.

UN/ISDR. (2009). 2009 UN/ISDR terminology on disaster risk reduction. Geneva: United Nations International Strategy for Disaster Reduction (UN/ISDR).

UNEP (United Nations Environment Programme). (2004). Meeting of Coordinators of the Project on Capacity-Building through Partnership and Information and Communication Technology for Using. Indigenous Knowledge for Nature Conservation and Natural Disaster Management in Africa. Meeting report, Nairobi, Kenya, 3-4 November, 2004

UNEP. (2009). The Role of Ecosystem Management in Climate Change Adaptation and Disaster Risk Reduction. Issues paper prepared for the global platform for Disaster Risk Reduction. United Nations Environment Programme, Geneva, Switzerland.

WHO. (2012). Consultation on the Health Emergency Risk Management Framework and Improving Public Health Preparedness: Meeting Report, WHO Headquarters, Geneva, Switzerland, 21-23.

Wood, D. J., \& Gray, B. (1991). Toward a comprehensive theory of collaboration. The $\begin{array}{llll}\text { Journal of applied behavioral } & \text { science, } & 27(2), & 139-162 .\end{array}$ https://doi.org/10.1177/0021886391272001

World Disaster Report, (2018). Review of disaster events: Emergency Events Database (EM-DAT). Centre for Research on Epidemiology of Disasters (CRED), Brussels, Belgium.

\section{Copyright Disclaimer}

Copyright for this article is retained by the author(s), with first publication rights granted to the journal.

This is an open-access article distributed under the terms and conditions of the Creative Commons Attribution license (http://creativecommons.org/licenses/by/4.0/). 